\title{
The Pragmatic Case Study Method for Creating Rigorous and Systematic, Practitioner-Friendly Research
}

\author{
DANIEL B. FISHMAN ${ }^{\mathrm{a}, \mathrm{b}, \mathrm{c}}$
}

${ }^{\mathrm{a}}$ Graduate School of Applied and Professional Psychology, Rutgers University

b

Correspondence regarding this article should be addressed to Daniel B. Fishman, Graduate School of Applied and Professional Psychology, Rutgers University, 152 Frelinghuysen Road, Piscataway, NJ 08854

Email:dfish96198@aol.com

C An earlier version of this paper was presented at a May, 2012 case study conference in Lausanne, Switzerland. The conference was sponsored by the Institut Universitaire de Psychothérapie du DP-CHUV in collaboration with LARPsyDIS et LabDCI, Institut de Psychologie, Faculté des Sciences Sociales et Politiques, Université de Lausanne. As a follow-up to this conference, an earlier version of the paper was published in French in the journal Psychothérapies (Fishman, 2013).

\begin{abstract}
Psychotherapy case studies have the capacity to link directly to the work of practitioners because these studies are grounded in the same type of setting in which clinicians function, that of the single case. Not surprisingly, then, case studies have played a most important role in the development of a wide range of therapy models, like psychoanalysis, behavioral therapy, and client-centered therapy. However, until recently, case studies as a method of research have fallen into disuse because they have been viewed as subjective and journalistic. This situation has changed with the growth of the philosophical movement of postmodernism, which has encouraged pluralism in the social sciences, and in turn stimulated new approaches to the case study as a serious method for psychotherapy research. This paper reviews one such approach, the pragmatic case study method, which is grounded in the fast-growing "mixed methods" model in the social sciences that seeks new ways to integrate qualitative and quantitative research designs and data. This paper begins with an overview of the growing variety of types of psychotherapy research, indicating where case studies fit in and describing a new design that integrates the use of pragmatic case studies with randomized clinical trials. The paper then lays out the basic structure of the pragmatic case study, in the context of viewing therapy as a complex adaptive system and, in a related fashion, as an example of Peterson's (1991) "Disciplined Inquiry" model of professional practice. The paper next provides a more concrete idea of the pragmatic case study by summarizing guidelines for writing such a case study for this PCSP journal, and by describing the structure of a specific example of a pragmatic case study published in the journal, the case of Caroline by Ueli Kramer. Finally, the paper describes how the pragmatic case study can be integrated with other types of case study designs.
\end{abstract}

Key words: systematic case studies; pragmatic case studies; postmodernism; pluralism; psychotherapy research; randomized clinical trials (RCTs); case studies; clinical case studies 


\section{AN OVERVIEW OF THE ROLE OF CASE STUDIES IN PSYCHOTHERAPY RESEARCH}

Case studies have played a key role in developing and demonstrating a wide variety different psychotherapy models. Some famous examples include:

- $\quad$ in psychoanalysis, Sigmund Freud's cases of Dora and Little Hans;

- $\quad$ in behavior therapy, J.B. Watson's case of Little Albert and B. F. Skinner's insistence that behavioral principles of learning be studied one organism at a time;

- in cognitive therapy, Aaron Beck and colleagues’ book, Cognitive Therapy in Clinical Practice: An Illustrative Casebook;

- in client-centered therapy, Virginia Axline’s case of Dibbs; and

- in existential therapy, Irvin Yalom's book of cases, Love’s Executioner \& Other Tales of Psychotherapy

And yet starting in the 1920s and gaining strength and going forward until recently, case studies have generally been viewed as journalistic and subjective, and only group studies have been considered as scientific (Fishman, 1999, 2005). This has created a vicious circle, with systematic and rigorous case study methods not being developed, resulting in case studies actually remaining as journalistic and subjective. In this scholarly environment, group studiesparticularly the randomized clinical trial (RCT) — have remained the "gold standard" of therapy research (American Psychological Association, 2006). However, beginning in the 1960s and gaining strength since then, the postmodern movement in philosophy, the arts, architecture, anthropology, and some of the other social sciences has had an increasing impact on clinical psychology and associated trends in psychotherapy research (Denzin \& Lincoln, 2011; Fishman, 1999, 2005; Gergen, 1991). Specifically, since postmodern epistemology views reality as socially constructed by specific groups of people at specific points in time, this epistemology emphasizes that the validity of statements about the psychological and social world are dependent upon acknowledging different perspectives and situating the statements in particular contexts. This is the idea behind Geertz's (1973) concept of "deep description," which is a method for

explaining with as much detail as possible the reason behind human actions. For example one could say a man winked. However, this would not explain why he winked: was he flirting, did he have something in his eye, [or] was he trying to communicate irony in what he had just said? (p. 6)

When this epistemological paradigm is applied to social science research, including psychotherapy research, the result is a focus on the value of qualitatively thick and rich, contextually embedded, and holistically described case cases in contributing to fundamental, disciplinary knowledge (Denzin \& Lincoln, 2011; Fishman, 1999; McLeod, 2010; Miller, 2004). 
In the context of this growing interest in methodological pluralism, there are now at least 18 different possible methodological types of psychotherapy research, and these are outlined in the grid shown in Table 1, with sample references. As can be seen from the table, the 18 types are generated by three different dimensions: (a) the type of data collected-primarily qualitative vs. quantitative vs. an integrated combination of the two (see more below about the latter, quickly growing "mixed methods" model); (b) the type of setting in which the research is collected: experimental vs. naturalistic; and (c) the focus of the data analysis: by individual cases vs. by groups of individuals vs. by a combination of both individual cases and groups. Some examples of the most frequently employed research designs are listed in the table. As shown,

- Cell A1 consists of qualitative, naturalistic studies, like clinical and narrative case reports in psychoanalysis or person-centered therapy.

- Cell A2 consists of qualitative comparisons across groups of clinical case reports.

- Cell C1 consists of the collection of standardized quantitative outcome data or process data within naturalistic practice, referred to as "practice-based evidence" and "process-oriented individual studies," respectively.

- Cell C2 consists of the collection of standardized quantitative outcome data or process data within naturalistic practice, referred to as "effectiveness research" or "process-oriented group research," respectively.

- Cell D1 consists of "single-case experimental designs," involving the collection of quantitative information over time about single individuals in response to experimental interventions.

- Cell D2 consists of randomized clinical trials (RCTs), whose logic is well known.

- Cell E1 consists of single case studies that employ both qualitative and quantitative data. These can involve "pragmatic case studies," which emphasize the use of such case studies as exemplars of best clinical practice; adjudicational case studies, which emphasize the intensive, "hermeneutic" evaluation of a case's process and outcome via multiple types of data as analyzed by multiple judges; and "theory-building case studies," whose purpose is to use cases to create and revise general theories of psychotherapy process and outcome.

- Cell F3 consists of the analysis of successful and unsuccessful single cases representatively drawn from RCT designs. As described in more detail below, this type of study uses both qualitative and quantitative data to compare and contrast the knowledge derived from the cases and from the RCT group design.

It is important to note that in John McLeod's (2010) important book on case study research in psychotherapy, he elaborates upon a number of types of such research. Table 1 indicates the chapters in McLeod's book that are associated with some of the particular types of research listed in row 1 of the table. 


\section{MIXED METHODS}

The "mixed methods" movement is based upon a new epistemological paradigm in medicine, education, and the social sciences, which provides numerous alternative procedures and rationales for how quantitative and qualitative data can be integrated (e.g., see Tashakorrie \& Teddlie, 2003; Tashakkori \& Creswell, 2007; Teddlie \& Tashakkori, 2009). The mixed methods model starts with the assumption that quantitative and qualitative data each have their own strengths but also weaknesses in validly describing the world, and thus combining both types of data provides a more valid overall picture of the phenomenon being studied. So, for example, numerical, quantitative data have the advantages of (a) stable meanings across time; (b) the ability to achieve quality control via established psychometric procedures; (c) the capacity to efficiently reduce large amounts of complex differences among the multiple individual cases included in group research designs; (d) the ability to obtain an objective, normative context for comparing individual clients; and (e) the capacity to create top-down deductive laws (Stiles, 2006).

We know, however, that the capacity of numbers to achieve reliability among different observers and their ability to reduce large and complex bodies of information is offset by their disadvantages in oversimplifying information, discarding much that is valuable. It is just this type of "lost" information that words and qualitative description excel at: (a) creating thick descriptions that include the detail, complexity, context, subjectivity, and multifaceted nature of human knowledge; (b) capturing the narrative, storytelling structures of human knowledge; and (c) having the capacity to ground generalizations in particular instances, so that the generalizations are derived from the bottom up (Fishman, 1999).

In psychotherapy outcome research the complementary strengths of quantitative and qualitative data translate into the fact that they are positioned to answer different research questions. This can be seen by examining the typical structure of an RCT, as shown in Table 2. The table illustrates this structure with a study comparing an experimental condition of CBT treatment for a problem such as depression, and a control condition of a "waiting list" control. The advantage of the quantitative group data is that it can answer a question like: Is the experimental condition on average more effective than the non-treatment control condition? Specifically, as shown in the table, since $60 \%$ of the clients in the experimental condition were successful compared to $20 \%$ in the no-treatment control condition, the answer to the question is that the experimental condition was on average more effective than the control condition.

In contrast, the advantage of the qualitative case study data is that they can answer questions like: Why did some particular individual clients in the experimental condition-like subjects E01 and E02-have successful therapy outcomes, while other subjects in the experimental condition-like E13 and E14_did not? Were there different reasons for success between E01 and E02? and Did patients E13 and E14 have different reasons for their therapeutic failures? Qualitative case studies can answer these questions and similar questions about the differences between patients in the control condition, like subjects C21 and C22, who had successful outcomes compared with subjects C25 and C26, who had unsuccessful outcomes. In sum, quantitative group data are of value in describing general relationships across groups of subjects involving a few variables, while qualitative case data are of value in thickly described 
processes within individual cases, processes that can vary in complex patterns between and among individual patients.

\section{APPLYING MIXED METHODS TO PSYCHOTHERAPY RESEARCH}

Because of the complementarity of qualitative and quantitative methods, I teamed up with two colleagues (Dattilio, Edwards, \& Fishman, 2010) to propose a mixed methods approach for integrating qualitative, case-oriented and quantitative, group-oriented approaches in psychotherapy, called the "Case Studies Within RCT Designs" model (see Table 1, cell 3F). Our proposal states that a new "gold standard" for conducting RCTs should require that their design and write-up include systematic case studies drawn from the experimental group of the RCT, and perhaps also from the control group. Specifically, we propose that all RCTs should be designed to include several parallel studies and associated publications that involve:

randomized controlled trials, qualitative examinations of the implementation of treatment programs, and systematic case studies, ... [ [together with] a review that offers an overall synthesis of the findings from different methodological approaches (2010, p. 427).

As an initial pilot example of this proposal, this journal recently published an issue titled, "The 'Individual-Case-Comparison' Method for Systematically Comparing Good-Outcome and PoorOutcome RCT Clients" (Fishman, 2011). In the issue, two RCTs were selected: one on Dialectical Behavior Therapy for clients with borderline personality disorder (Burckell \& McMain, 2011), and one on Emotion-Focused Therapy for clients with depression (Goldman, Watson, \& Greenberg, 2011; Watson, Goldman, \& Greenberg, 2011). For each RCT, a successful and an unsuccessful client were drawn from the experimental condition and the process of the therapy was compared and contrasted for these two individuals.

With three other colleagues (Frank Dattilio, Stanley Messer, and David Edwards), I now have a book under contract with Oxford University Press to further develop the case studies within RCT designs model. The book's working title is, Case Studies Within Clinical Trials: Integrating Qualitative and Quantitative Methods (or "Cases Within Trials," for short). The core of the book will consist of four chapters, each by a senior RCT researcher and each including (a) description and discussion of a successful RCT following high quality methodological standards; (b) two or three systematic case studies drawn from the experimental condition of the RCT; and (c) a synthesis of the two different types of knowledge emerging from (a) and (b). In order to tap into a diversity of clinical phenomena, the chapters will include borderline personality disorder in adults, depression in adults, anxiety in children, and depression in adolescents. A range of theoretical perspectives are involved-specifically and respectively, transference-focused psychoanalytic therapy, motivational interviewing, cognitive-behavior therapy, and interpersonal psychotherapy. 


\section{THE BASIC STRUCTURE OF THE INDIVIDUAL CLINICAL CASE: THERAPY AS A COMPLEX ADAPTIVE SYSTEM AND AS AN EXAMPLE OF "DISCIPLINED INQUIRY"}

Therapy intervention models that have been successfully tested by RCT designs are called "empirically supported treatments." One approach recommends adoption of such treatments as a model for best practice (Klonsky, 2012). A paradigm for creating such empirically supported treatments is Peterson's (1991) "Applied Science" model, shown in Figure 1. This model starts with basic science that then creates applied research, which then translates into technology (e.g., a manualized treatment for a particular disorder like depression), which is then applied by a therapist to a client's presenting problem. When it comes to looking in depth at the complexity and contexts of individual cases, the applied science model by itself is intrinsically quite limited by being based on relatively few variables and a focus on linear relationships with one-way-only causality.

In contrast, therapy can be seen as a "complex adaptive system" (CAS; Eidelson, 1997). In other words, therapy can be viewed as composed of a diverse collection of many interconnected parts organized into subsystems that are frequently interconnected via nonlinear relationships and reciprocally causal influences. A diagram of therapy as a CAS is shown in Figure 2 (from Goodheart, 2011). In the figure, a "consumer's" (patient's) mental health and medical conditions - which can be interconnected-are indicated in the center. The consumer circle on the left and the clinician circle on the right reflect the many swirling influences that affect outcomes, with interactions between them shown in a continuous feedback loop.

The patient brings fears, hopes, strengths, limitations, attitudes, and personal circumstances into the treatment room. These will affect engagement with the treating psychotherapist, responses to what is offered, and willingness to change, depending on the match or mismatch with what the clinician presents and the strength of the impinging influences. The clinician brings to the endeavor his or her clinical training, level of ability to maintain an alliance and a focus on patient goals, and level of flexibility to modify treatment as needed, as well as personal and professional attitudes and circumstances. The changing internal and external environments for each party influence the possibilities for success of treatment. Instead of a linear path, the drawing highlights the complex interaction between patient, problem, and clinician, as well as implying the reciprocity of influences on outcome, [including the changing external environment]. (Goodheart, 2011, p. 344).

Translating the CAS model into the recognized components of best psychotherapy practice yields a view of therapy that Peterson (1991) labels "Disciplined Inquiry," as shown in Figure 3. Unlike the contrasting Applied Science model in Figure 1, which ends with the client and which is linear, the Disciplined Inquiry model starts with the client and is not just linear, but includes four feedback loops. More specifically, in the Disciplined Inquiry model in Figure 3, the therapist begins with a focus on the Client and his or her presenting problems (component A). In this context, the therapist selects a general Guiding Conception (component B) with accompanying Clinical Experience and Research Support (component C). The therapist then conducts a comprehensive Assessment (component D), including history, personality, living situation, symptoms and other problems, diagnosis, and strengths. Applying the Guiding 
Conception to the Assessment data then yields an individualized Formulation and Treatment Plan (component E). This plan is implemented during the Course of Therapy (component F). This clinical process is consistently subjected to Therapy Monitoring (component G), generating feedback loops. If the therapy is not proceeding well, possible changes in the formulation and treatment plan might be required (see component $\mathrm{H}$ ); and if the case is going well and meeting the needs of the client, arrangements for termination in consultation with the client might be made (component I). If the Therapy Monitoring results in showing that the client has been successful and/or the therapist and client agree that further therapy will not be productive, therapy is terminated and a Concluding Evaluation (component L) is conducted. This can yield feedback for either confirming — via assimilation — the original Guiding Conception (component $\mathrm{J}$ ), or revising that theory through accommodation (component $\mathrm{K}$ ).

It is important to note that the Disciplined Inquiry model incorporates many of the virtues typically associated with best practice. For example,

- Components A \& G. Best practice is pragmatically driven based on client needs and goals.

- Components B \& C. Best practice incorporates theory, past research, and past clinical experience. (No particular theory is favored, as long as it is clearly articulated and supported by empirical evidence.)

- Components D \& E. Best practice requires the clinician to differentiate between descriptive assessment and the inferences and hypotheses associated with formulation.

- Component F and E. Best practice calls for a systematic, narrative description of the therapeutic process, linking it to the theoretical themes and processes from the Formulation and Treatment Plan.

- Components G \& L. Best practice calls for systematic evaluation, involving both qualitative information and the use of standardized quantitative measures, which place the individual case and its outcome in normative context

- Components H-K. Best practice calls for an examination of how monitoring and feedback loops impact on the therapy.

To translate the structure in Figure 3 into common headings for a systematic case study, I have developed 11 subheadings for the case studies that are published in this PCSP journal. The subheadings are shown at the bottom of Figure 3.

The American Psychological Association (2006) has developed a well-known model of best practice, labeled "Evidence-Based Practice in Psychology." The approach posits that best practice is a three-legged stool consisting of the best research evidence (associated with empirically supported treatments), the patient's values and preferences, and the clinical expertise of the therapist. These legs are captured in the Disciplined Inquiry model in Figure 3, with the Client and Assessment components A and D reflecting the client's perspective; the Guiding Conception with relevant Clinical Experience and Research Support components B and C reflecting the best research evidence; and the Formulation and Treatment Plan, Course of 
Therapy, Therapy Monitoring, Concluding Evaluation, and feedback loops—components E-K— representing clinical expertise.

\section{FROM SINGLE CASE TO DATABASE: THE PRAGMATIC CASE STUDIES IN PSYCHOTHERAPY (PCSP) JOURNAL}

Drawing on the above ideas, in 2005 I founded this PCSP journal, which is an open access, peer reviewed, online journal of pragmatic case studies and case study method articles. The term "pragmatic" was chosen to emphasize the case studies' outcome focus on what works and what doesn't work; their pluralism in method, including both qualitative and quantitative data in their designs; and pluralism in their theoretical orientations, that is, PCSP case studies can be conducted within any theoretical orientation, as long it is clearly articulated and supported by empirical research and scholarship. Consistent with this last point, PCSP has a multi-theoretical editorial board of 60 prominent therapy researchers and scholars representing different theoretical traditions (see: http://pcsp.libraries.rutgers.edu/index.php/pcsp/about/pcspEditorialTeam). In this same pluralistic vein, as one way of ensuring critical analysis, the publication of most case studies includes two or more critical commentaries from different perspectives, with a reply to the commentaries by the case study author.

The on-line nature of the journal has a number of advantages. First, online journals don't have page limitations like print journals, allowing for the space needed for a thorough thick description of the case along with a presentation of its full theoretical details. Second, the online nature of the material allows for full-text searching for scholarly analysis. Finally, an online journal is capable of holding a large database of systematic case studies, to facilitate inductive generalization across individual cases. Over time this is crucial as any single case has substantial limitations in generalizability, so the more cases of a particular theoretical, presenting problem, and demographic type, the more powerful the capacity to generalize.

Another important aspect of the PCSP journal is that each case study is organized according to the Disciplined Inquiry model in Figure 3 by following the 11 headings listed in the figure. This not only grounds each case study in a best practice structure, but by using a common framework for each case, it facilitates cross-case comparisons.

To provide a concrete idea of the nature of the systematic case studies sought and published in PCSP, Table 3 presents guidelines for authors of such studies, again using the 11 headings listed in Figure 3.

A good example of a case study published in PCSP is the case of Caroline by Ueli Kramer (2009). An outline of the case is presented in Table 4 , illustrating how the structure in Figure 3 and how the practical guidelines in Table 3 should be implemented.

Finally, above and in Table 1 I mention McLeod's (2010) typology of different kinds of psychotherapy case studies, including: (a) the pragmatic case study, which constitutes a comprehensive case study that serves as an exemplar of best clinical practice; (b) the theorybuilding case study, whose purpose is to use cases to create and revise general theories of 
psychotherapy process and outcome; (c) the adjudicational case study, which focuses on the intensive, "hermeneutic" evaluation of a case's process and outcome via multiple types of data as analyzed by multiple judges to determine truth claims about the therapy; (d) the narrative case study, which focuses on capturing the personal meaning of the therapy experience for both client and clinician; and (e) the single-case experimental design, which looks at quantitative changes over time in response to controlled variations in therapeutic conditions. PCSP publishes all five types of case studies.

In a recent article (Fishman, 2012), I pointed out that while all five models of case studies identified by McLeod draw on the same qualitative and quantitative data that comprise a particular episode of psychotherapy, the models vary in the scope and kind of data they focus on and analyze. The most comprehensive is the pragmatic case study, which has the broadest and most descriptive focus, including the various components of best practice and their interrelationships (see Figure 3). The other models are more selective in the data they analyze and have a less descriptive focus, including, respectively, psychotherapy data that are specifically focused on theory-building; on the adjudication of particular truth claims; on narrative meaning; and on response to different controlled conditions.

In the words of the earlier article,

In fact, the case study content (although not necessarily the methods) of the other four models are included in the Pragmatic Case Study (PCS) model. Thus the PCS model includes theory-building (see component B, the Guiding Conception, in Figure 3); the adjudication-related search for particular conclusions about the nature and causes of therapy (see component L, Concluding Evaluation); a description of the narrative experiences of the client and therapist (see component F, Course of Therapy); and quantitative data about the effects of different therapy conditions [as in single-case experimental designs] on outcome (see component G, Therapy Monitoring). What the other four models add is the opportunity to "zoom in" with more detail and conceptual elaboration on particular aspects of the case study, employing a different study design.

While each of the five case study models yields valuable types of knowledge in themselves, I have proposed that there are advantages to combining two or more of the models in the same case study, so that in general, the knowledge from different perspectives on the same case can enrich each other. The value of this type of enrichment by multiple perspectives has been argued both by social constructionists (e.g., Fishman, 1999; Gergen, 1991) and by mixed methods advocates (e.g., Teddlie \& Tashakorrie, 2009). As editor of the PCSP journal, I have therefore encouraged such combined designs. Particularly, in light of the point above that the Pragmatic Case Study contains the basic content of the other four models, I have encouraged case study authors to choose a Pragmatic Case Study design as a broader, more descriptive foundation upon which the more selective perspective of an alternative case study model can then be elaborated (Fishman, 2012, p. 248).

Examples of an article in PCSP combining a pragmatic case study with a narrative case design can be found by Singer and Bonalume (2010); two combining a pragmatic case study and an adjudicated case study design can be found by Miller and colleagues (e.g., Miller, 2011) and by Bohart and colleagues (e.g., Bohart, Berry, \& Wicks, 2011); and one combining pragmatic 
case studies and a single-case experimental design can be found by Folke, Von Bahr, AssadiTalaremi, and Ramnerö (2012).

\section{SUMMARY}

The pragmatic case study method is designed to create research that is both practitionerfriendly, and rigorous and systematic. The method is responsive to practitioner needs by directly linking to the actual clinical practice of therapy via the individual case. The method is connected to scientific research designs in that it is embedded in the recently developed mixed methods model (Teddlie \& Tashakorrie, 2009), including (a) qualitative data that are rich, descriptive, directly observed in context, and carefully documented; (b) quantitative data that are rigorous and standardized, and capable of statistical analysis; and (c) interpretation of data within the context of a scholarly, theoretical, empirical, and peer-reviewed literature. Through the Case Studies Within RCT Designs model, case studies can link to the "gold standard" body of RCT research. At the same time, the concept of "single-case to database" means that as more and more cases accumulate, their power to generalize increases, and thus their capacity to contribute to the improvement of theoretical and practical knowledge about psychotherapy increases.

\section{REFERENCES}

American Psychological Association (2006). Evidence-based practice in psychology. American Psychologist, 61, 271-285.

American Psychological Association (2009). Publication manual of the American Psychological Association, 6th edition. Washington, DC: American Psychological Association.

Barkham, M., \& Margison, F. (2007). Practice-based evidence as a complement to evidencebased practice: From dichotomy to chiasmus. In. C. Freeman \& M. Power (Eds.)., Handbook of evidence-based psychotherapies: A guide for research and practice, pp. 443-476. Chichester: John Wiley \& Sons.

Barkham, M., Stiles, W.B., Connell, J., Mellor-Clark, J. (2012). Psychological treatment outcomes in routine NHS services: What do we mean by treatment effectiveness? Psychology and Psychotherapy: Theory, Research and Practice, 85,1-16.

Barlow, D.H., Nock, M.K., \& Hersen, M. (2008). Single case experimental designs: Strategies for studying behavior change (3rd Edition). Boston: Allyn \& Bacon

Bohart, A.C., Berry, M., \& Wicks, C. (2011). Developing a systematic framework for utilizing discrete types of qualitative data as therapy research evidence. Pragmatic Case Studies in Psychotherapy, 7(1), Article 9, 145-155. Available: http://hdl.rutgers.edu/1782.1/pcsp_journal

Burckell, L.A., \& McMain, S. (2011). Contrasting clients in Dialectical Behavior Therapy for borderline personality disorder: "Marie" and "Dean," two cases with different alliance trajectories \& outcomes. Pragmatic Case Studies in Psychotherapy, 7(2), Article 2, 246267. Available: http://hdl.rutgers.edu/1782.1/pcsp_journal

Dattilio, F.M., Edwards, D.J.A., \& Fishman, D.B. (2010). Case studies within a mixed methods paradigm: Toward a resolution of the alienation between researcher and practitioner in psychotherapy research. Psychotherapy Theory, Research, Practice, Training, 47, 427441. 
The Pragmatic Case Study Method for Creating Rigorous and Systematic, Practitioner-Friendly Research

Denzin, N.K., \& Lincoln, Y.S. (Eds.). (2011). The SAGE handbook of qualitative research, 4th edition. Thousand Oaks, Ca: Sage.

Eidelson, R.J. (1997). Complex adaptive systems in the behavioral \& social sciences. Review of General Psychology, 1, 42-71

Elliott, Robert, R., ; Partyka, R., Alperin, R., Dobrenski, R., Wagner, J., Messer, S.B., Watson, J.C., \& Castonguay, L.G. (2009). An adjudicated hermeneutic single-case efficacy design study of experiential therapy for panic/phobia. Psychotherapy Research, 19, 543-557.

Fishman, D.B. (1999). The case for pragmatic psychology. New York: NYU Press.

Fishman. D.B. (2005.) Editor's introduction to PCSP-From single case to database. Pragmatic Case Studies in Psychotherapy, 1(1), Article 2, 1-50. Available: http://hdl.rutgers.edu/1782.1/pcsp_journal

Fishman, D.B. (2011). The "Individual-Case-Comparison" method for systematically comparing good-outcome and poor-outcome RCT clients: Editor's introduction. Pragmatic Case Studies in Psychotherapy, 7(2), Article 1, 242-245. Available: http://hdl.rutgers.edu/1782.1/pcsp_journal

Fishman, D.B. (2013). L' etude de cas pragmatique: une methode de recherche rigoureuse et systematique qui parle aux praticiens. Psychothérapies, 33, 3-12.

Folke, F., Von Bahr,M., Assadi-Talaremi, V., \& and Ramnerö, R. (2012). Exposure and response prevention in the treatment of body dysmorphic disorder-A case series. Pragmatic Case Studies in Psychotherapy, 8(4), Article 2, 255-287. Available: http://hdl.rutgers.edu/1782.1/pcsp_journal

Geertz, C. (1973). The interpretation of cultures. New York: Basic Books.

Gergen, K. (1991). The saturated self. New York: Basic Books.

Glebova, T., Foster, S.L.. Cunningham, P.B., Brennan, P.A., \& Whitmore, E. (2012). Examining therapist comfort in delivering family therapy in home and community settings: Development and evaluation of the Therapist Comfort Scale. Psychotherapy, 49, 52-61.

Goldman, R. N, Watson, J.C., \& Greenberg, L. S. (2011). Contrasting two clients in EmotionFocused Therapy for depression 2: The case of "Eloise," "It's like opening the windows and letting the fresh air come in." Pragmatic Case Studies in Psychotherapy, 7(2), Article 4, 305-338. Available: http://hdl.rutgers.edu/1782.1/pcsp_journal

Goodheart, C.D. (2011). Design for tomorrow. American Psychologist, 66, 339-347.

Jacobson, N.S., \& Truax, P. (1991). Clinical significance: A statistical approach to defining meaningful change in psychotherapy research. Journal of Consulting and Clinical Psychologv, 59, 12-19.

Klonsky, E.D. (Ed.). Website on research-supported psychological treatments by the Division of Clinical Psychology of the American Psychological Association. http://www.div12.org/PsychologicalTreatments/index.html

Kramer, U. (2009). Individualizing exposure therapy for PTSD: The case of Caroline. Pragmatic Case Studies in Psychotherapy, 5(2), Article 1, 1-24. Available: http://hdl.rutgers.edu/1782.1/pcsp_journal

Mackrill, T. (2011a). A diary-based, cross-contextual case study methodology: Background for the case of "Jane and Joe.” Pragmatic Case Studies in Psychotherapy, 7(1), Article 10, 156-186. Available: http://hdl.rutgers.edu/1782.1/pcsp_journal 
The Pragmatic Case Study Method for Creating Rigorous and Systematic, Practitioner-Friendly Research

Pragmatic Case Studies in Psychotherapy, http://pcsp. libraries.rutgers. edu

Volume 9, Module 4, Article 2, pp. 403-425, 12-12-13 [copyright by author]

Mackrill, T. (2011b). The case of "Jane and Joe": A diary-based, cross-contextual case study. Pragmatic Case Studies in Psychotherapy, 7(1), Article 11, 187-229. Available: http://hdl.rutgers.edu/1782.1/pcsp_journal

McLeod, J. (2010). Case study research in counselling and psychotherapy. London: Sage.

Messer, S.B. (2007). Psychoanalytic case studies and the pragmatic case study method. Pragmatic Case Studies in Psychotherapy, 3(1), Article 4, 55-58. Available: http://hdl.rutgers.edu/1782.1/pcsp_journal

Michel, L., Kramer, U., \& De Roten, Y. (2011). Alliance evolutions over the course of shortterm dynamic psychotherapy: A case study. Counselling and Psychotherapy Research, $11,43-54$.

Miller, R.B. (2004). Facing human suffering: Psychology and psychotherapy as moral engagement. Washington, DC: American Psychological association.

Miller, R.B. (2011). Real Clinical Trials (RCT'): Panels of Psychological Inquiry for transforming anecdotal data into clinical facts and validated judgments: Introduction to a pilot test with the case of “Anna.” Pragmatic Case Studies in Psychotherapy, 7(1), Article 2, 6-36. Available: http://hdl.rutgers.edu/1782.1/pcsp_journal

Nathan, P.E., \& Gorman, J.M. (2007). A guide to treatments that work, 3rd edition. New York: Oxford University Press.

Norcross, J.E. (Ed.). (2011). Psychotherapy relationships that work: Evidence-based responsiveness, 2nd edition. New York: Oxford University Press.

Peterson, D.R. (1991). Connection and disconnection of research and practice in the education of professional psychologists. American Psychologist, 46, 422-429.

Stiles, W.B. (2006). Numbers can be enriching. New Ideas in Psychology, 24, 252-262

Stiles, W.B. (2009). Logical operations in theory-building case studies. Pragmatic Case Studies in Psychotherapy, 5(3), Article 2, 9-22. Available: http://hdl.rutgers.edu/1782.1/pcsp_journal

Stiles, W.B. (2011). Coming to terms. Psychotherapy Research, 21, 367-384

Stiles, W.B., Barkham, M., Mellor-Clark, J., Connell, J. (2008). Effectiveness of cognitivebehavioural, person-centred, and psychodynamic therapies in UK primary-care routine practice: Replication in a larger sample. Psychological Medicine, Vol 38, 677-688.

Tashakkori, A., \& Creswell, J.W. (2007). Editorial: The new era of mixed methods. Journal of Mixed Methods Research, 1, 3-7.

Tashakorrie, A., \& Teddlie, C. B. (2003). Handbook of mixed methods in social and behavioral research. Thousand Oaks, CA: Sage.

Teddlie, C.B., \& Tashakorrie, A. (2009). Foundations of mixed methods research: Integrating quantitative and qualitative approaches in the social and behavioral sciences. Thousand Oaks, CA: Sage.

Timulak, L. (2009). Meta-analysis of qualitative studies: A tool for reviewing qualitative research findings in psychotherapy. Psychotherapy Research, 19, 591-600.

Watson, J.S., Goldman, R.N., \& Greenberg, L.S. (2011). Contrasting two clients in EmotionFocused Therapy for depression 1: The case of "Tom," "Trapped in the tunnel." Pragmatic Case Studies in Psychotherapy, 7(2), Article 3, 268-304. Available: http://hdl.rutgers.edu/1782.1/pcsp_journal 
D.B. Fishman

Pragmatic Case Studies in Psychotherapy, http://pcsp.libraries.rutgers.edu

Volume 9, Module 4, Article 2, pp. 403-425, 12-12-13 [copyright by author]

Table 1. Methods for Studying the Phenomena of Psychotherapy,

Which Consists of Individual Cases and Collections of Them in Groups

\begin{tabular}{|c|c|c|c|c|c|c|}
\hline & \multicolumn{2}{|c|}{ Qualitative Methods } & \multicolumn{2}{|c|}{ Quantitative Methods } & \multicolumn{2}{|c|}{$\begin{array}{c}\text { Mixed Methods } \\
\text { (Both Qualitative \& Quantitative) }\end{array}$} \\
\hline & $\begin{array}{l}\text { A. Naturalistic } \\
\text { Setting }\end{array}$ & $\begin{array}{l}\text { B. Experi- } \\
\text { mental } \\
\text { Setting }\end{array}$ & $\begin{array}{l}\text { C. Naturalistic } \\
\text { Setting }\end{array}$ & $\begin{array}{l}\text { D. Experimental } \\
\text { Setting }\end{array}$ & E. Naturalistic Setting & $\begin{array}{l}\text { F. Experimental } \\
\text { Setting }\end{array}$ \\
\hline 1. Case-Based & $\begin{array}{l}\text { Psychoanalytic case } \\
\text { reports } \\
\text { (Messer, 2007) } \\
\text { Narrative case reports } \\
\text { (Mackrill, 2011a, } \\
\text { 2011b) - } \\
\text { see McLeod (2010, } \\
\text { Chapter 10)* }\end{array}$ & \# & $\begin{array}{l}\text { "Practice-Based } \\
\text { Evidence" (Barkham } \\
\text { \& Margison, 2007) } \\
\\
\text { Process-Oriented } \\
\text { Case Studies (Michel } \\
\text { et al., 2011) }\end{array}$ & $\begin{array}{l}\text { Single-Case } \\
\text { Experimental } \\
\text { Designs (Barlow et } \\
\text { al., 2008) - } \\
\text { see McLeod (2010, } \\
\text { Chapter 7) }\end{array}$ & $\begin{array}{l}\text { "Pragmatic Case Studies" } \\
\text { (Fishman, 2005) - } \\
\text { see McLeod (2010,Chapter } \\
\text { 6) } \\
\text { Adjudicational case studies, } \\
\text { e.g., the "Hermeneutic Single } \\
\text { Case Efficacy Design" } \\
\text { (HSCED; Elliott, 2009) - } \\
\text { see McLeod (2010, Chapter } \\
\text { 8) } \\
\text { "Theory-Building Case } \\
\text { Studies" (Stiles 2009, 2011) } \\
\text {-- see McLeod (2010, } \\
\text { Chapter 9) }\end{array}$ & \# \\
\hline 2. Group-Based & $\begin{array}{l}\text { Comparisons across } \\
\text { clinical case reports } \\
\text { (Timulak, 2009) }\end{array}$ & \# & $\begin{array}{l}\text { "Effectiveness } \\
\text { Research" (Stiles et } \\
\text { al., 2008; Barkham et } \\
\text { al., 2012) } \\
\text { Process-Oriented } \\
\text { Group Research } \\
\text { (Glebova et al., 2012) }\end{array}$ & $\begin{array}{l}\text { Randomized Clinical } \\
\text { Trials (RCTs), also } \\
\text { called "Efficacy } \\
\text { Research" (Nathan } \\
\text { and Gorman, 2007; } \\
\text { Norcross, 2011) }\end{array}$ & \# & \# \\
\hline $\begin{array}{l}\text { 3. Both Case- } \\
\text { Based \& } \\
\text { Group-Based }\end{array}$ & $\#$ & $\#$ & \# & $\#$ & $\#$ & $\begin{array}{l}\text { Case Studies } \\
\text { Within RCT } \\
\text { Designs (Dattilio } \\
\text { et al., 2010) }\end{array}$ \\
\hline
\end{tabular}

* "McLeod (2010)" refers to a book on psychotherapy case studies. For a description of relevance to the table, see the text.

\# Blank cells represent less frequently employed research designs. 
The Pragmatic Case Study Method for Creating Rigorous and Systematic, Practitioner-Friendly Research

Table 2. Typical Outcome Structure of a Randomized Clinical Trial (RCT) for a Problem Like Depression

\begin{tabular}{|l|l|}
\hline $\begin{array}{l}\text { Experimental } \\
\text { Condition, e.g., } \\
\text { CBT treatment for } \\
\text { depression }\end{array}$ & E01, E02, E03, E04, E05 \\
& $\begin{array}{l}\text { E11, E12, E13, E14, E15 } \\
\text { E16, E17, E18, E19, E20 } \\
\text { (60\% successful) }\end{array}$ \\
\hline $\begin{array}{l}\text { Control Condition, } \\
\text { e.g. "waiting list" } \\
\text { control }\end{array}$ & $\begin{array}{l}\text { C21, C22, C23, C24, C25 } \\
\text { C26, C27, C28, C29, C30 } \\
\text { C31, C32, C33, C34, C35 } \\
\text { C36, C37, C38, C39, C40 } \\
\text { (20\% successful) }\end{array}$ \\
\hline
\end{tabular}

Successful resolution of depression

Unsuccessful resolution of depression 
Table 3. Practical Guidelines for Conducting and Writing Up a Pragmatic Case Study

\begin{tabular}{|c|c|}
\hline $\begin{array}{l}\text { Section of a } \\
\text { Pragmatic Case } \\
\text { Study (PCS): see } \\
\text { list of the } 11 \text { sub } \\
\text { headings in } \\
\text { Figure } 3 \text { ) }\end{array}$ & Guidelines \\
\hline 1-8. Overall & $\begin{array}{l}\text { A. Be systematic, properly covering each of sections 1-8 and their } \\
\text { interrelationships, ensuring a common structure with other pragmatic case studies. } \\
\text { B. Clearly differentiate description from theory. } \\
\text { C. Remember that the goal of a PCS is primarily to describe and interpret what } \\
\text { happened in this particular case as a basic unit of knowledge in the field-not } \\
\text { primarily to illustrate or confirm a theory, strategy, or procedure. }\end{array}$ \\
\hline 4-8. Overall & $\begin{array}{l}\text { A. Provide enough clinical description of the case (differentiated from theory) so } \\
\text { that the case could be interpreted from a different theoretical model than the } \\
\text { Guiding Conception presented. } \\
\text { B. Ground the case in examples from the assessment data and the course of } \\
\text { therapy data. }\end{array}$ \\
\hline $\begin{array}{l}\text { 1. Case Context and } \\
\text { Method }\end{array}$ & $\begin{array}{l}\text { A. Include your background and the setting of the case (research, training, } \\
\text { community clinic, private practice, etc.) } \\
\text { B. Provide credibility checks of your description and interpretation, e.g., } \\
\text { supervisors, independent interviewers, standardized tests, third-party observers, } \\
\text { and/or third-party coders of transcripts. }\end{array}$ \\
\hline 2. The Client & $\begin{array}{l}\text { A. Offer a short introduction to the case. } \\
\text { B. Pay careful attention to full disquise of the case. }\end{array}$ \\
\hline $\begin{array}{l}\text { 3. Guiding } \\
\text { Conception with } \\
\text { Research and } \\
\text { Clinical Experience } \\
\text { Support }\end{array}$ & $\begin{array}{l}\text { A. Write the Guiding Conception so that it is free-standing. Since PCSP is a multi- } \\
\text { theoretical journal, assume the reader doesn't necessarily know the theory itself } \\
\text { or the jargon associated with the theory in the Guiding Conception. } \\
\text { B. Be scholarly by relating to the published literature, including the case study } \\
\text { literature. }\end{array}$ \\
\hline $\begin{array}{l}\text { 4. Assessment of } \\
\text { the Client's } \\
\text { Problems, Goals, } \\
\text { Strengths, and } \\
\text { History. }\end{array}$ & $\begin{array}{l}\text { A. Be detailed by using thick description. } \\
\text { B. Use multiple types of data to reduce error of measurement. }\end{array}$ \\
\hline $\begin{array}{l}\text { 5. Formulation and } \\
\text { Treatment Plan }\end{array}$ & $\begin{array}{l}\text { In the Formulation and Treatment Plan, clearly bridge the Guiding Conception with } \\
\text { the Assessment data. }\end{array}$ \\
\hline
\end{tabular}




\section{Table 3 (continued)}

\begin{tabular}{|c|c|}
\hline $\begin{array}{l}\text { Section of a } \\
\text { Pragmatic Case } \\
\text { Study (PCS): see } \\
\text { list of the } 11 \\
\text { subheadings in } \\
\text { Figure 3) }\end{array}$ & Guidelines \\
\hline $\begin{array}{l}\text { 6. Course of } \\
\text { Therapy }\end{array}$ & $\begin{array}{l}\text { A. Ground your description in examples. } \\
\text { B. Employ a matrix structure: organize your description by } 2 \text { dimensions-create } \\
\text { phases by chronologically grouping sessions, and organize these phases by } \\
\text { theoretical themes in the Guiding Conception and/or by pragmatic and strategic } \\
\text { themes in the therapy process. } \\
\text { C. Connect actual course of therapy to the treatment plan. }\end{array}$ \\
\hline $\begin{array}{l}\text { 7. Therapy } \\
\text { Monitoring and Use } \\
\text { of Feedback } \\
\text { Information }\end{array}$ & $\begin{array}{l}\text { A. Describe how you monitored the therapy as it proceeded. } \\
\text { B. Describe how monitoring data was used as feedback and impacted the course } \\
\text { of therapy. }\end{array}$ \\
\hline $\begin{array}{l}\text { 8. Concluding } \\
\text { Evaluation of the } \\
\text { Therapy's Process } \\
\text { and Outcome }\end{array}$ & 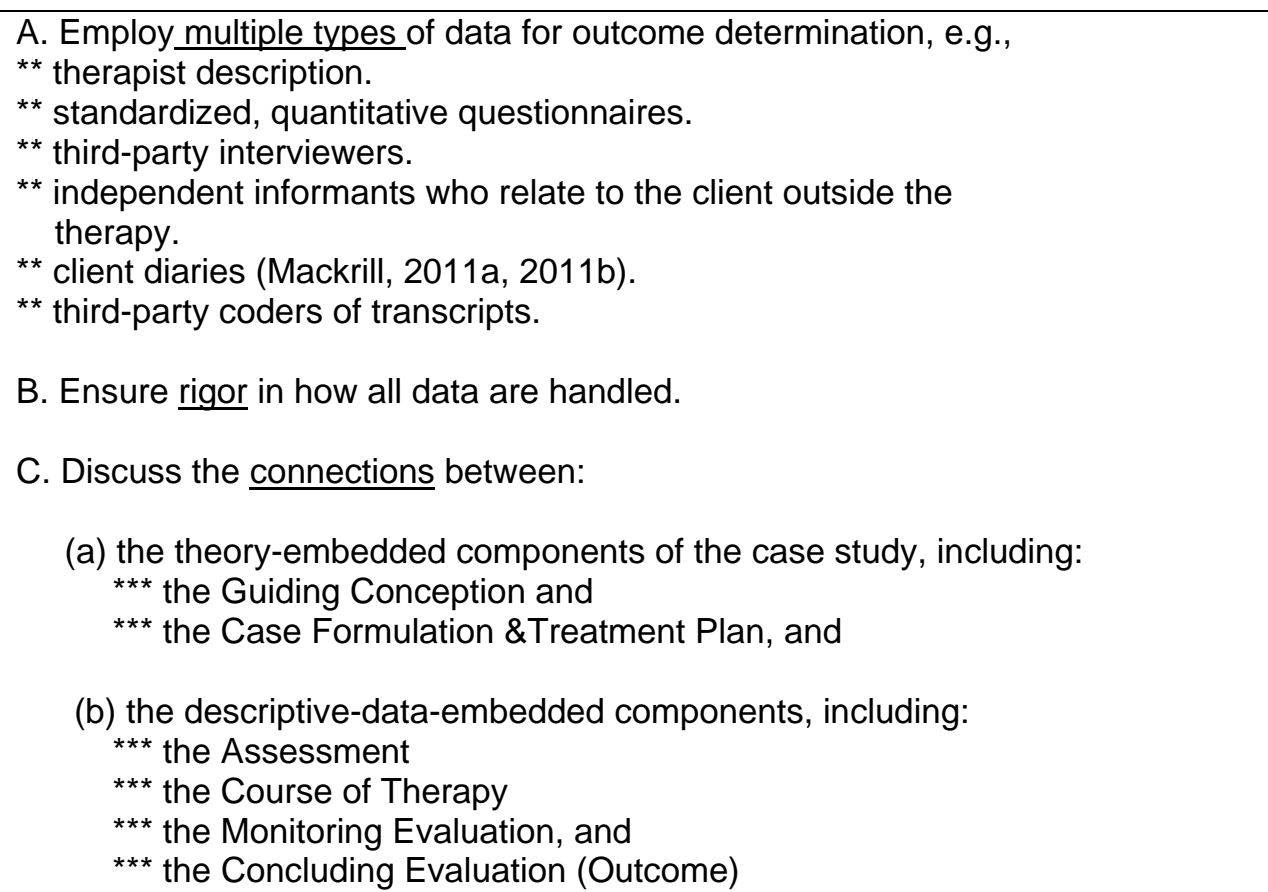 \\
\hline 9. References & Employ the Style Manual of the American Psychological Association (2009). \\
\hline $\begin{array}{l}\text { 10. \& 11. Tables and } \\
\text { Figures }\end{array}$ & Place the Tables and Figures at the end of the manuscript. \\
\hline
\end{tabular}


Table 4. Summary of the Structure of a Model Pragmatic Case Study: The Case of Caroline (Kramer, 2009)

\begin{tabular}{|c|c|}
\hline $\begin{array}{l}\text { Section of a } \\
\text { Pragmatic } \\
\text { Case Study } \\
\text { (PCS): see list } \\
\text { of the } 11 \text { sub } \\
\text { headings in } \\
\text { Figure 3) }\end{array}$ & Summary of Sample Content \\
\hline Abstract & $\begin{array}{l}\text { "[Manualized] prolonged exposure (PE) to stimuli associated with an original trauma } \\
\text { experience ... [was applied to] the year-long, } 40 \text {-session treatment of [26-year-old] } \\
\text { Caroline, an adult [PTSD] female victim of child sexual abuse. The manual was } \\
\text { supplemented by Caspar's... Plan Analysis technique [and Motive-Oriented } \\
\text { Therapeutic Relationships (MOTRs)] for individualized case formulation and treatment } \\
\text { planning. ... As indicated by standardized, quantitative measures, by changes in the } \\
\text { client's behavior patterns, and by the client's subjective report, the treatment was very } \\
\text { effective. An analysis of the therapy process illustrates the importance of a combination } \\
\text { of manual-based procedures with individualized case formulations and interventions. } \\
\text { The case is discussed in the context of enhancing the cognitive-behavioral treatment of } \\
\text { PTSD" (Kramer, 2009, p. 1). }\end{array}$ \\
\hline $\begin{array}{l}\text { 1. Case } \\
\text { Context and } \\
\text { method }\end{array}$ & $\begin{array}{l}\text { A. Rationale for Selecting This Particular Client for Study. } \\
\text { - Background behind using prolonged exposure supplemented by supportive } \\
\text { counseling, imaginative relaxation, and plan analysis. } \\
\text { B. The Methodological Strategies Employed for Enhancing the Rigor of the Study } \\
\text { - } 3 \text { regular case supervision sessions. } \\
\text { - Therapist took detailed notes, in order to be able to reflect upon the process. } \\
\text { Standardized self-report measures used for symptom assessment, monitoring, and } \\
\text { outcome measurement during therapy, and at follow-up. } \\
\text { C. Clinical Setting in Which the Case Took Place } \\
\text { - The therapy took place at a public psychiatric clinic and charges were paid by the } \\
\text { client's public health insurance, according to the Swiss Federal Law. }\end{array}$ \\
\hline 2. The Client & $\begin{array}{l}\text { "When treatment began, Caroline was } 26 \text { years old and experiencing clinically } \\
\text { significant depression. She reported that she was sexually abused by her maternal } \\
\text { grandfather, from age } 12 \text { to } 14 \text {. As a result, she had a history of major PTSD-related } \\
\text { problems in maintaining romantic relationships. At the time she entered therapy, she } \\
\text { had been living for four years in an abusive intimate relationship with 'Sylvia,' a } 40 \text {-year- } \\
\text { old bi-sexual. Caroline was working as secretary for a small local company" (Kramer, } \\
2009, \text { p. 2). }\end{array}$ \\
\hline $\begin{array}{l}\text { 3. Guiding } \\
\text { Conception } \\
\text { With Research } \\
\text { \& Clinical } \\
\text { Experience } \\
\text { Support }\end{array}$ & $\begin{array}{l}\text { Three theory-based therapeutic strategies employed: } \\
\text { - } \quad \text { Prolonged Exposure Therapy } \\
\text { - Imaginative Relaxation } \\
\text { - } \quad \text { Plan Analysis and the Development of } \\
\quad \text { "Motive-Oriented Therapeutic Relationships"(MOTRs) }\end{array}$ \\
\hline
\end{tabular}


Table 4 (continued)

\begin{tabular}{|c|c|}
\hline $\begin{array}{l}\text { Section of a } \\
\text { Pragmatic } \\
\text { Case Study } \\
\text { (PCS): see list } \\
\text { of the } 11 \text { sub } \\
\text { headings in } \\
\text { Figure } 3 \text { ) }\end{array}$ & Summary of Sample Content \\
\hline $\begin{array}{l}\text { 4. Assessment } \\
\text { of the Client's } \\
\text { Problems, } \\
\text { Goals, } \\
\text { Strengths, and } \\
\text { History }\end{array}$ & 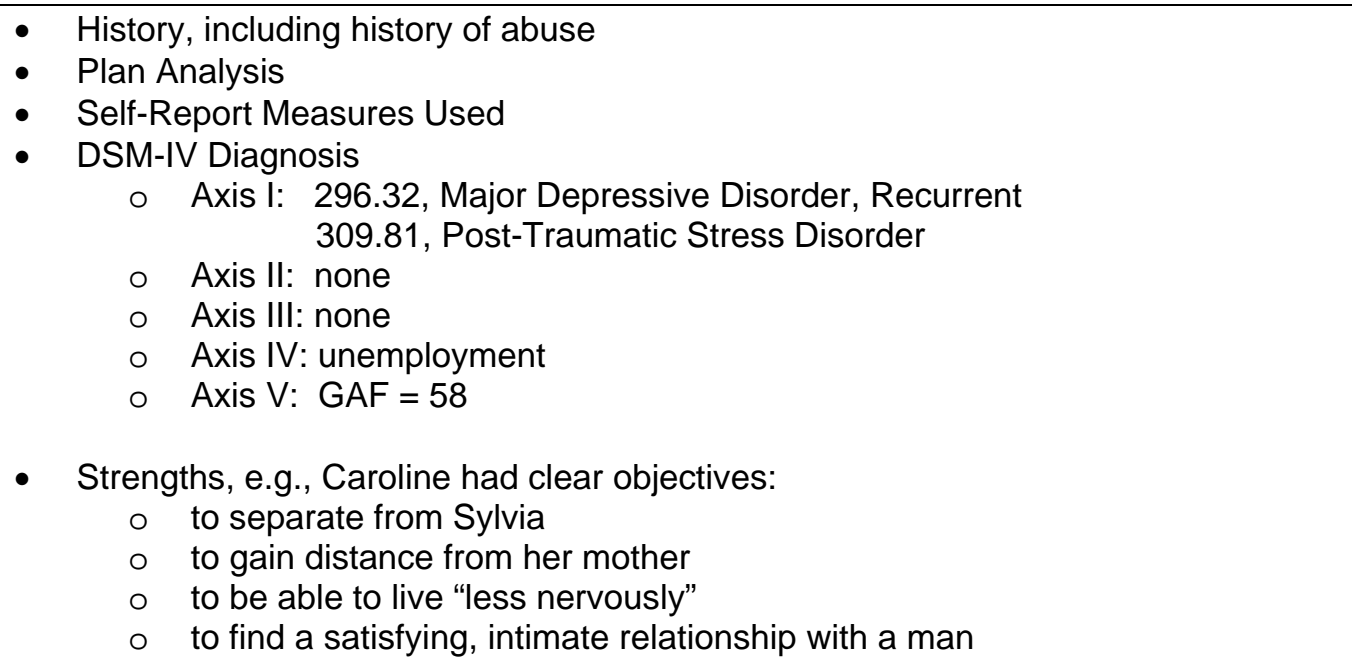 \\
\hline $\begin{array}{l}\text { 5. Formulation } \\
\text { \& Treatment } \\
\text { Plan }\end{array}$ & $\begin{array}{l}\text { - } \quad \text { Cognitive-behavioral formulation and treatment plan } \\
\text { - Using the Plan Analysis results to design a strategy for } \\
\text { creating a Motive-Oriented Therapeutic Relationship } \\
\text { - Treatment goals }\end{array}$ \\
\hline $\begin{array}{l}\text { 6. Course of } \\
\text { Therapy }\end{array}$ & $\begin{array}{l}\text { Sessions 1-10: Establishing a Working Alliance } \\
\text { - } \quad \text { "In line with Caroline's strengths, I underlined several of her positive, approach } \\
\text { Plans, such as '9-Be a good mother,' '14-Search for other's compassion,' and '15- } \\
\text { Assert yourself.' Regarding \#9, I pointed out that Sylvia had children Caroline liked } \\
\text { to care for, and I asked if she also had other girlfriends with young children for } \\
\text { whom she could imagine offering some help. This was acknowledged by Caroline, } \\
\text { but even if there were not any girlfriends around, this comment aimed at raising the } \\
\text { awareness about her Plan '9-Be a good mother' and about its possible satisfaction, } \\
\text { for which she could enjoy caring about children other than Sylvia's" (Kramer, 2009, } \\
\text { p. 11). } \\
\text { Sessions 11-15: Separating from Sylvia } \\
\text { "In the following session, Caroline came with a big smile and said she wrote the } \\
\text { letter [to Sylvia documenting her unhappiness with the relationship], and while } \\
\text { writing it, she gained so much insight about the relationship that she decided to call } \\
\text { Sylvia [to terminate the relationship]" (Kramer, 2009, p. 11). } \\
\text { Sessions 16-20: A Crisis with Disturbing Eating Problems } \\
\text { Address with "cognitive crisis intervention ... [e.g.,.] by an eating diary to be } \\
\text { completed every day after every meal ... [to help ]the client [and therapist] to } \\
\text { become aware of the day-by-day links between the eating disturbance and Sylvia's } \\
\text { inner affective life" (p. 12). } \\
\text { Address eating problem with Imaginative Relaxation as a way to reduce anxiety. }\end{array}$ \\
\hline
\end{tabular}


Table 4 (continued)

\begin{tabular}{|c|c|}
\hline $\begin{array}{l}\text { Section of a } \\
\text { Pragmatic } \\
\text { Case Study } \\
\text { (PCS): see list } \\
\text { of the } 11 \\
\text { subheadings } \\
\text { in Figure } 3 \text { ) }\end{array}$ & Summary of Sample Content \\
\hline $\begin{array}{l}\text { 6. Course of } \\
\text { Therapy } \\
\text { (continued) }\end{array}$ & $\begin{array}{l}\text { Sessions 21-23: In Vivo Exposure to Men in Group Settings } \\
\text { Sessions 24-26: In Sensu (Imaginative) Exposure to Abuse-Related Events } \\
\text { - Following the manual, Caroline listens to tape recordings of sessions in which she } \\
\text { talks about past abuse. } \\
\text { - "Caroline mentioned that while listening to the tape at home, she thought of herself as } \\
\text { being a 12-year-old child, dangerously vulnerable and helpless, and at the mercy of } \\
\text { adults ... feelings associated with [the sexual abuse with] her abusive grandfather" } \\
\text { (Kramer, 2009, p. 13). } \\
\text { "Based on Caroline's upset anticipation of the in sensu exposure, we then agreed not } \\
\text { to proceed with it as previously planned, but to maintain tape-recording of at least the } \\
\text { next } 10 \text { sessions and, as homework, to have Caroline listen at home to each session } \\
\text { in the days following it" (Kramer, 2009, p. 14). } \\
\text { Sessions 27-40: Switch from In Sensu Exposure to Enhancement of Social Competence } \\
\text { "Crucially, the therapeutic focus then shifted from specific symptom reduction to work } \\
\text { on the therapeutic relationship and related social relationships. This included relevant, } \\
\text { underlying interpersonal schemas ... that were activated by the therapeutic relationship } \\
\text { and were linked to her traumatic sexual experience in adolescence, without } \\
\text { elaborating explicitly the narrative of that experience. In this context, there was a focus } \\
\text { on Caroline's experience in recent social situations that had been difficult for her, ... } \\
\text { devoted to enhancement of her social competence in interpersonal relationships, e.g., } \\
\text { with her mother and with men, whom she had previously avoided" (Kramer, 2009, p. } \\
\text { 14). }\end{array}$ \\
\hline $\begin{array}{l}\text { 7. Therapy } \\
\text { Monitoring and } \\
\text { Use } \\
\text { of Feedback } \\
\text { Information }\end{array}$ & $\begin{array}{l}\text { Use of quantitative measures at the beginning, middle, and end of therapy, } \\
\text { and at follow-up } \\
\text { Use of supervision sessions at strategic points }\end{array}$ \\
\hline $\begin{array}{l}\text { 8. Concluding } \\
\text { Evaluation of } \\
\text { the } \\
\text { Therapy's } \\
\text { Process and } \\
\text { Outcome }\end{array}$ & $\begin{array}{l}\text { Qualitative data } \\
\text { At the end of treatment, Caroline is in a romantically and sexually satisfying } \\
\text { relationship with a man that eventually led to becoming engaged to him. } \\
\text { At the end of treatment, Caroline is more distanced from and assertive in relationships } \\
\text { with her mother and Sylvia. } \\
\text { Quantitative data } \\
\text { Over treatment and at follow-up, statistically and clinically significant improvements in } \\
\text { the quantitative measures (see Table 5) } \\
\text { Discussion }\end{array}$ \\
\hline
\end{tabular}


The Pragmatic Case Study Method for Creating Rigorous and Systematic, Practitioner-Friendly Research

Pragmatic Case Studies in Psychotherapy, http://pcsp.libraries.rutgers.edu

Volume 9, Module 4, Article 2, pp. 403-425, 12-12-13 [copyright by author]

Table 5. Outcome of Caroline’s Psychotherapy (see Table 4, section 8)

\begin{tabular}{|c|c|c|c|c|c|c|}
\hline Scale & $\begin{array}{c}\text { Clinical } \\
\text { Cut-Off } \\
\text { Score }^{b}\end{array}$ & $\begin{array}{l}\text { Session } 1 \\
\text { score }\end{array}$ & $\begin{array}{l}\text { Session } 29 \\
\text { score }\end{array}$ & $\begin{array}{l}\text { Session } 40 \\
\text { score }\end{array}$ & $\begin{array}{c}\text { 3-Months } \\
\text { Follow-up } \\
\text { Score }\end{array}$ & $\begin{array}{c}\text { 6-Months } \\
\text { Follow-up } \\
\text { score }\end{array}$ \\
\hline $\mathrm{GSI}^{\mathrm{a}}$ & .8 & 2.4 & $1.5\left(8.89^{c^{*}}\right)$ & $.4\left(19.76^{*} \#\right)$ & $.3\left(20.75^{*} \#\right)$ & $.4\left(19.76^{* \#)}\right.$ \\
\hline PSS-SR & 1.0 & 1.46 & $.78\left(4.57^{*} \#\right)$ & $.26\left(8.06^{*} \#\right)$ & .39 (7.19*\#) & $.31\left(7.73^{*} \#\right)$ \\
\hline BDI & 16 & 26 & $15\left(5.43^{* \#}\right)$ & 2 (11.85*\#) & $5(10.37 * \#)$ & $3(11.36 * \#)$ \\
\hline STAI-S & 46 & 41 & $42(-.24)$ & $45(-.98)$ & $43(-.49)$ & $45(-.98)$ \\
\hline STAI-T & 52 & 71 & $68(.73)$ & 38 (8.07*\#) & $44(6.60 * \#)$ & $42(7.09 * \#)$ \\
\hline
\end{tabular}

${ }^{a}$ GSI: General Symptom Index of Symptom Checklist 90-Revised (SCL-90-R) PSS-SR: Posttraumatic Stress Symptoms Self-Report

BDI: Beck Depression Inventory

STAI-S: Spielberger Anxiety Inventory - State

STAI-T: Spielberger Anxiety Inventory - Trait

${ }^{\mathrm{b}}$ Score at or below which a client's functioning is in the normal, non-pathological range.

${ }^{\mathrm{c}}$ Reliable Change Index (RCI; Jacobson \& Truax, 1991) values compared to intake session are in parentheses.

$* \mathrm{p}<.05$, for RCI values greater than 1.96

\# “Clinically significant change” by Jacobson and Truax’s (1991) standard, i.e., a statistically significant change on a scale in which the client begins above the clinical cut-off score and has an end state at or below the clinical cut-off score, thus in the normal range of functioning. 
The Pragmatic Case Study Method for Creating Rigorous and Systematic, Practitioner-Friendly Research

Pragmatic Case Studies in Psychotherapy, http://pcsp.libraries.rutgers. edu

Volume 9, Module 4, Article 2, pp. 403-425, 12-12-13 [copyright by author]

Figure 1. Model Behind the Empirically Supported Treatments (EST) Approach:

Therapy as "Applied Science” (D.R. Peterson, 1991)

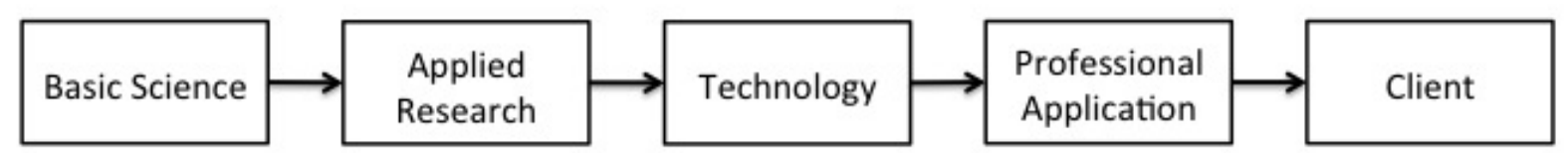


Pragmatic Case Studies in Psychotherapy, http://pcsp.libraries.rutgers.edu

Volume 9, Module 4, Article 2, pp. 403-425, 12-12-13 [copyright by author]

Figure 2. Therapy as a Complex System (CAS; Goodheart, 2011)

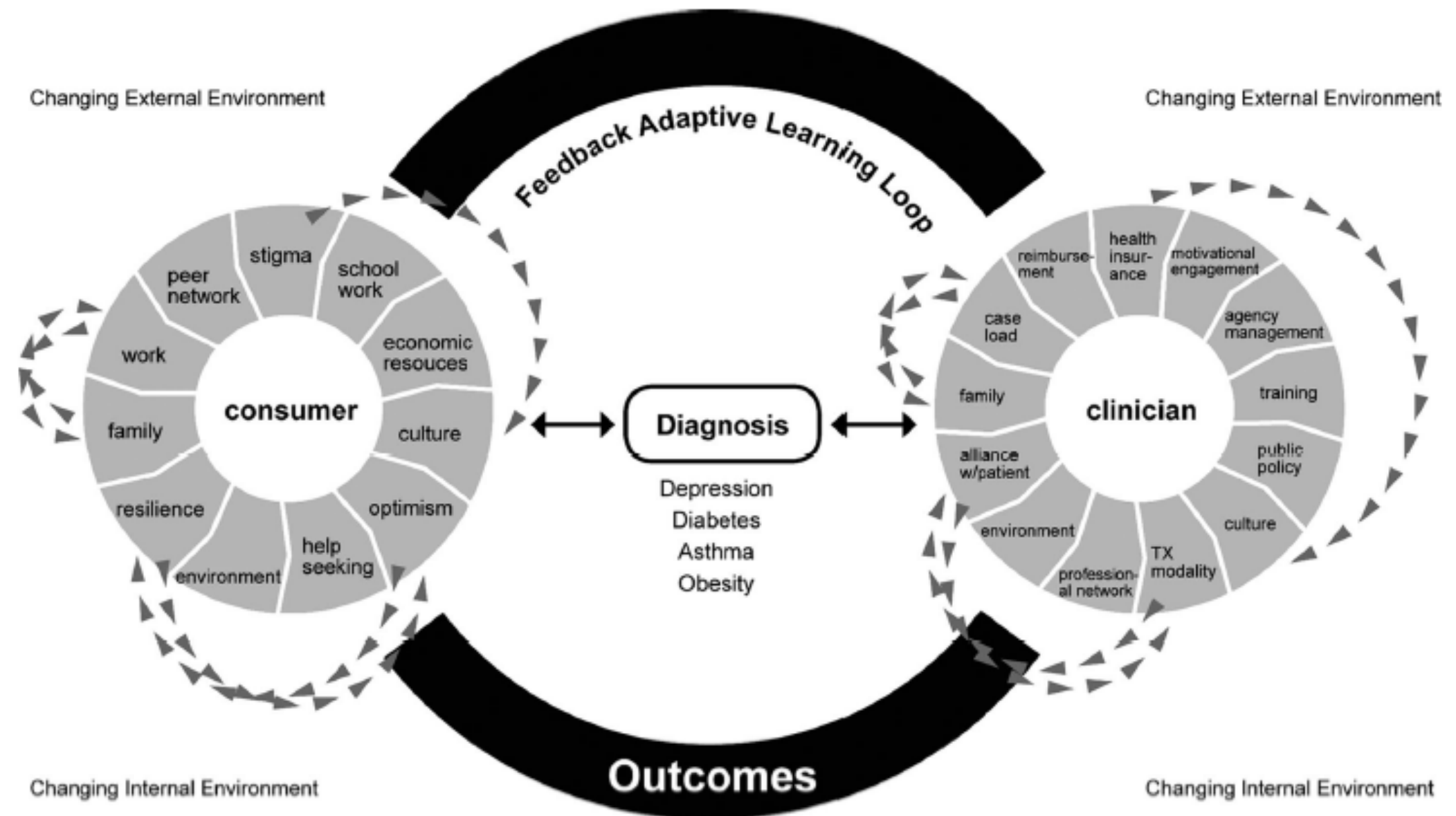

Note. Adapted from a slide in Outcomes Measurement: APA Presidential Task Force on Advancing Practice, a presentation by Ann Doucette to the APA Practice Organization's State Leadership Conference, March 2010, Washington, DC. Copyright 2010 by Ann Doucette. Adapted with permission. 
Figure 3. Translating the CAS Model of Therapy into the Recognized Components of Best Practice:

Therapy as “Disciplined Inquiry” (adapted from D.R. Peterson, 1991)

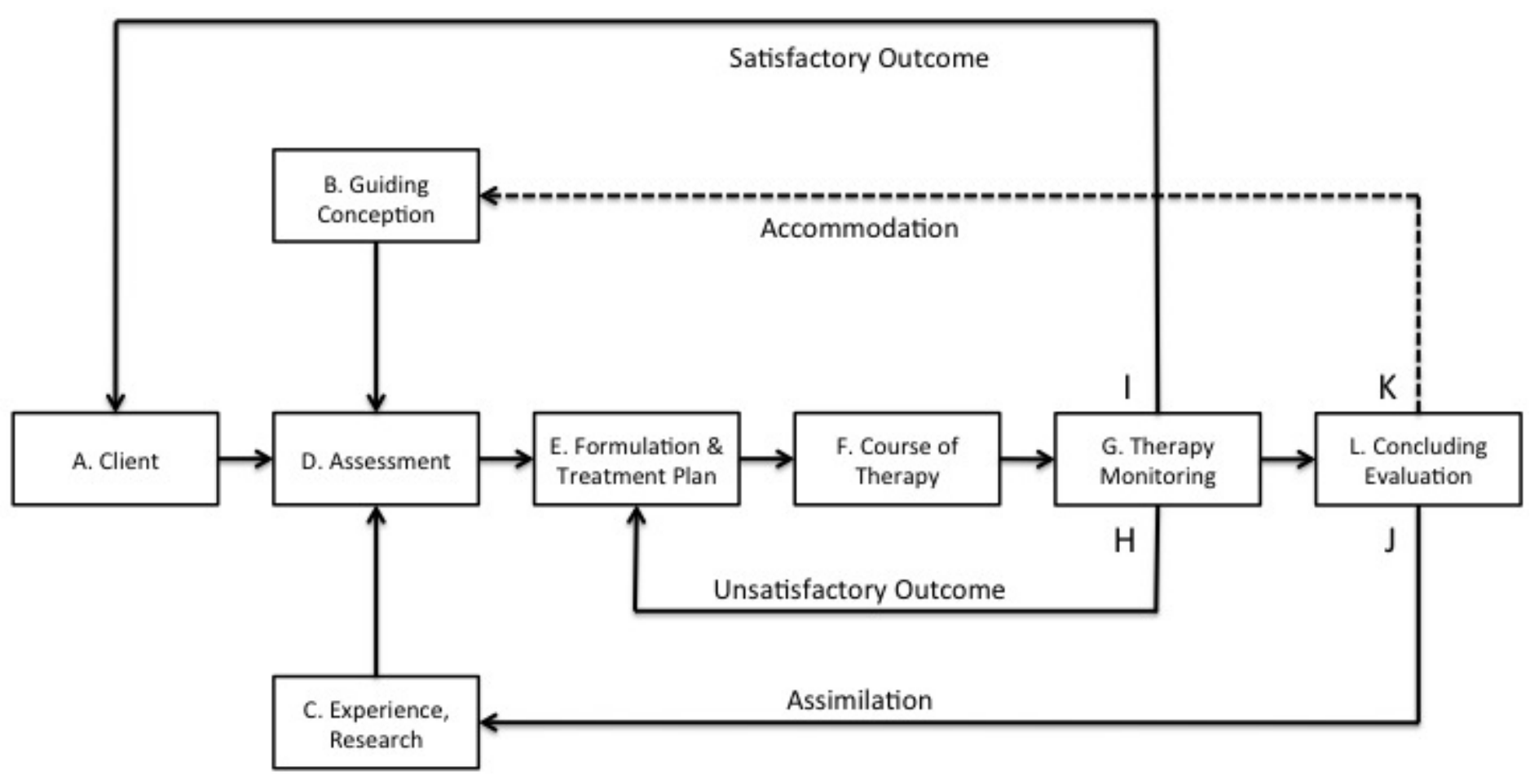

\section{Common Headings in a Pragmatic Case Study}

1. Case Context and Method

2. The Client $[\mathrm{A}]$

3. Guiding Conception [B] with Research and Clinical Experience Support [C]

4. Assessment of the Client's Problems, Goals, Strengths, and History [D]

5. Formulation \& Treatment Plan [E]

6. Course of Therapy [F]

7. Therapy Monitoring and Use of Feedback Information [G, H, I]

8. Concluding Evaluation of the Therapy's Process and Outcome [J, K, L]

9. References

10. Tables (optional)

11. Figures (optional) 